JSRM Code: 010020200006

ISSN $0973-7154$

\title{
Umbilical Cord Blood Banking for Transplantation in Morocco: Problems and opportunities
}

\author{
Mazini $\mathrm{L}^{1}$, Matar $\mathrm{N}^{2 \#}$, Bouhya $\mathrm{S}^{3 \#}$, Marzouk $\mathrm{D}^{4,5}$, Anwar $\mathrm{W}^{4,5}$, Khyatti $\mathrm{M}^{1}$
}

Since the success of the first umbilical cord blood (UCB) transplantation in a child with Fanconi anaemia in 1989, great interests have emerged for this source of stem cells. UCB provides an unlimited source of ethnically diverse stem cells and is an alternative for bone marrow (BM) and peripheral blood (PB) haematopoietic stem cell transplantation (HSCT). Thus, UCB and manipulated stem cells are now collected and banked according to international accreditation standards for listing on registries allowing rapid search and accessibility worldwide. This work aims to identify problems limiting the creation of a Moroccan cord blood bank and to highlight opportunities and issues of a new legislation promoting additional applications of cell therapy.

Key Words: Umbilical Cord Blood Banking, Related donor, Unrelated donor, Legislation, Morocco

\section{Introduction}

Umbilical Cord Blood transplantation (UCBT) was first reported in 1989 by Gluckman E. et al ${ }^{[1]}$ and UCB is now routinely used as a source of Haematopoietic Stem Cells (HSC). The major advantage of this source is the acceptable degree of human leukocyte antigen (HLA) mismatch compared to bone marrow (BM). It is more and immediately accessible when no available BM HLAmatched donors are found ${ }^{[2-5]}$. In addition, UCB presents less risks of transmissible viral infection than maternal blood ${ }^{[6]}$, and stem cells it contains present self-renewal, proliferative and immune-modulatory abilities ${ }^{[7]}$.

Furthermore, although UCB contains one log less nucleated cells than BM and Peripheral Blood (PB), UCB units are now successfully used in transplantation of patients with myeloid and lymphatic leukemia, lymphoma, myelodysplasia, aplastic anaemia, haemoglobinopathies, thalassaemia, immune deficiency, autoimmune and inherited metabolic diseases, and other diseases especially in children ${ }^{[1,2-8]}$. However, allogeneic UCBT is limited by HLA-matching and many previous reports correlated outcomes in engraftments to HLA disparity after UCBT in patients ${ }^{[3,4,8,9]}$.

Many other variables are influencing outcomes after UCBT in adults such as diagnosis and stage of disease, but the nucleated cell dose has been reported to be clearly associated with the engraftment and the risk of transplant-related events ${ }^{[10]}$. To overcome this cell dose restriction, double or multiple units of UCB are used
In children and adolescents ${ }^{[11]}$ and in adults with a reduced intensity conditioning to benefit older patients or those for which myeloablative conditioning remains too risky ${ }^{[4,15-17]}$.

As the immunologic complications of Graft Versus Host Disease (GVHD) usually offset the therapeutic benefits of unrelated BM transplants, the UCB selection criteria for unrelated transplantation were different regarding malignant and non-malignant diseases ${ }^{[11]}$. Specific strategies and transplant programs are developed to help in finding adequate grafts quality.

With the increasing therapeutic applications of related and unrelated UCB stem cells followed by the increased demand of UCB units, international organizations, registries and biobanks are created to improve good practices in UCB collection, manipulation and storage to achieve high quality for the UCB units, and to define standardized procedures for donor search and acquisition.

(http://factwebsite.org/CordSearch.aspx?\&type=CordBloodB ank\&country=\&state $=$ )

\section{FOCUS ON CORD BLOOD TRANSPLANTATION}

\section{Haematology disorders/ Oncology}

Several studies have shown that patients with acute leukemia are the most treated with UCB units in the absence of Matched-Related Donor (MRD) or Unrelated Donor (URD). After UCB HSC Transplantation (HSCT), the incidence and

Author Names in full: Loubna Mazini ${ }^{1}$, Nourredine Matar ${ }^{2}$, Said Bouhya ${ }^{3}$, Diaa Marzouk ${ }^{4,5}$, Wagida Anwar ${ }^{4,5}$, Meriem Khyatti ${ }^{1}$

${ }^{1}$ Laboratoire Cellules Souches et Thérapie Cellulaire, Institut Pasteur Maroc, Casablanca, 1 Place Pasteur, 20360 Casablanca, Morocco. ${ }^{2}$ Service Gynécologie Obstétrique, Matérnité Lalla Meryem B, Centre Hospitalier Universitaire (CHU) Ibn Rochd, Casablanca, Morocco. ${ }^{3}$ Service Gynécologie Obstétrigue, Maternité Lalla Meryem A, CHU Ibn Rochd, Casablanca, Morocco. ${ }^{4}$ Community Medicine Department, Faculty of Medicine, Ain Shams University, Cairo, Egypt, ${ }^{5}$ National Research Centre, Cairo, Egypt. \# Both the authors equally contributed to this work. 
severity of GVHD is less than observed with BM and $P B{ }^{[1,2,11]}$. This may be due to the functional immaturity of infused lymphocytes with a decreased cytotoxicity, an altered cytokine profile, a decreased HLA expression and an increased regulatory $T$ cell ${ }^{[12,19,20]}$. Other findings suggest that even if survival is similar after transplantation with MRD, URD and UCB in children with acute leukemia, occurrence of acute and chronic GVHD and relapse remain higher respectively in MRD and URD than in UCB group ${ }^{[21]}$, while survival after transplantation with URD UCB units is similar to Matched URD from $\mathrm{BM}^{[22]}$.
Furthermore, the outcomes of related or unrelated UCBT in children revealed the importance of the cell dose infused as a predictor of neutrophils and platelets engraftment ${ }^{[8,24]}$. In addition, the incidence of GVHD and chronic GVHD depends on the degree of HLA mismatch in both pediatric ${ }^{2,3,19,21,23,25-}$ 28] and adult patients ${ }^{[4,11,12,14-16,29-31]}$ as indicated in Table 1 and 2. In fact, the infusion of partially HLA-matched UCB units, neutrophils and platelets engraftment ranged from 26 32 days (Table 1 ) and 20-27 days (Table 2 ) in pediatric and adult patients, respectively. The overall survival also increased in groups with rapid neutrophils engraftment.

Table 1 : Umbilical Cord Blood Transplantation in Children with haematopoietic malianancies

\begin{tabular}{|c|c|c|c|c|c|c|c|c|c|}
\hline Reference & Number & $\begin{array}{l}\text { Age or } \\
\text { median }\end{array}$ & $\begin{array}{l}\text { Degree of } \\
\text { HLA match }\end{array}$ & $\begin{array}{l}\text { Neutrophil } \\
\text { engraftment } \\
\text { median or } \\
\%\end{array}$ & $\begin{array}{l}\text { Platelet } \\
\text { engraftment } \\
\text { median or } \\
\%\end{array}$ & $\begin{array}{l}\text { Acute GVHD } \\
\text { I-II (\%) }\end{array}$ & $\begin{array}{l}\text { Acute } \\
\text { GVHD III-IV } \\
(\%)\end{array}$ & $\begin{array}{l}\text { Chronic } \\
\text { GVHD }\end{array}$ & $\begin{array}{l}\text { Overall } \\
\text { survival } \\
\%\end{array}$ \\
\hline $\begin{array}{l}\text { Rocha et al. } \\
\text { 1990-1997 (19) }\end{array}$ & 113 & $5(<1-15)$ & $6 / 6$ & 26 days & 44 & 29/107 patients & $\begin{array}{l}\text { 2/107 } \\
\text { patients }\end{array}$ & $\begin{array}{l}5 / 93 \\
\text { surviving }\end{array}$ & $\begin{array}{l}46(2-3 \\
\text { years })\end{array}$ \\
\hline $\begin{array}{l}\text { Wagner et al. } \\
\text { 1994-1995 (23) }\end{array}$ & 13 & $\begin{array}{l}2,7(0,1- \\
21,3)\end{array}$ & $\begin{array}{l}6 / 6,1-2 / 6, \\
3 / 6 \text { or more }\end{array}$ & $24(16-53)$ & $54(39-130)$ & 16 & 11 & na & $\begin{array}{l}65 \text { at } 6 \\
\text { months }\end{array}$ \\
\hline $\begin{array}{l}\text { Dalle et al. } \\
\text { 1996-2002 } \\
\text { (3) }\end{array}$ & 30 & $\begin{array}{l}7,5(0,1- \\
19,5)\end{array}$ & $6 / 6,1-2 / 6$ & $28(16-49)$ & $43(18-59)$ & $\begin{array}{l}3 / 36 \text { (6 without } \\
\text { hematopietic } \\
\text { malignancies }\end{array}$ & 11 & $\begin{array}{l}3 / 36 \\
\text { surviving }\end{array}$ & $\begin{array}{l}59(2-3 \\
\text { years })\end{array}$ \\
\hline $\begin{array}{l}\text { Rocha et al. } \\
\text { 1994-1998 (2) }\end{array}$ & 99 & $6(2,5-10)$ & $\begin{array}{l}6 / 6,1-2 / 6, \\
3 / 6 \text { or more }\end{array}$ & $32(11-56)$ & $81(16-159)$ & 38 & 21 & $5 / 43$ patients & 35 \\
\hline $\begin{array}{l}\text { Kutzberg et al } \\
2008(25)\end{array}$ & 191 & 7,7 & & 27 & 174 & $\mathrm{Na}$ & 42 & $\begin{array}{l}21 \% \text { at } 2 \\
\text { years }\end{array}$ & $\begin{array}{l}51(1 \\
\text { year) }\end{array}$ \\
\hline $\begin{array}{l}\text { Smith et al. } \\
2009 \text { (26) }\end{array}$ & 21 & 4,2 & & $95 \%$ & na & $\mathrm{Na}$ & 1,2 & $\begin{array}{l}0,8 \text { (relative } \\
\text { risk } 95 \% \mathrm{Cl} \text { ) }\end{array}$ & $\begin{array}{l}43(5 \\
\text { years) }\end{array}$ \\
\hline $\begin{array}{l}\text { Yoo KH et al. } \\
1996-2003 \text { (27) }\end{array}$ & 236 & na & & 18 & 45 & $\mathrm{Na}$ & $\begin{array}{l}41,1 \\
\text { (Grade II- } \\
\text { IV) }\end{array}$ & $36,10 \%$ & $\begin{array}{l}47,5(5 \\
\text { years })\end{array}$ \\
\hline $\begin{array}{l}\text { Kato et al. } \\
2011 \text { (28) }\end{array}$ & 332 & 5 & & $89 \%$ day 90 & na & na & 46 & $19 \%$ & $\begin{array}{l}8(5 \\
\text { years) }\end{array}$ \\
\hline $\begin{array}{l}\text { Yi E.S et al } \\
2005-2010 \text { (21) }\end{array}$ & 41 & $\begin{array}{l}9,1(0,9- \\
18,7)\end{array}$ & & 19 & 51 & $\mathrm{Na}$ & $\begin{array}{l}24 \\
\text { (Grade II- } \\
\text { IV) }\end{array}$ & $9 \%$ & na \\
\hline
\end{tabular}


Table 2 : Umbilical Cord Blood Transplantation in Adults with haematopoietic malignancies

\begin{tabular}{|c|c|c|c|c|c|c|c|c|c|}
\hline Reference & Number & $\begin{array}{l}\text { Age or } \\
\text { median }\end{array}$ & $\begin{array}{l}\text { Degree of } \\
\text { HLA match }\end{array}$ & $\begin{array}{l}\text { Neutrophil } \\
\text { engraftment } \\
\text { median or \% }\end{array}$ & $\begin{array}{l}\text { Platelet } \\
\text { engraftment } \\
\text { median or \% }\end{array}$ & $\begin{array}{l}\text { Acute GVHD } \\
\text { I-II (\%) }\end{array}$ & $\begin{array}{l}\text { Acute GVHD } \\
\text { III-IV (\%) }\end{array}$ & $\begin{array}{l}\text { Chronic } \\
\text { GVHD }\end{array}$ & $\begin{array}{l}\text { Overall } \\
\text { survival \% }\end{array}$ \\
\hline $\begin{array}{l}\text { Rocha et al. } \\
\text { 1998-2002 (29) }\end{array}$ & 98 & $24,5(15-55)$ & $6 / 6,2 / 6,3 / 6$ & $26(14-80)$ & na & 13 & 13 & $\begin{array}{l}18 / 16 \\
\text { surviving }\end{array}$ & 63 (2-3 years) \\
\hline $\begin{array}{l}\text { Wagner et al. } \\
1994-2001 \text { (8) }\end{array}$ & 65 & $7,4(0,2-56,9)$ & $6 / 6,2 / 6,3 / 6$ & $23(9-54)$ & $86(29-276)$ & $51 / 63$ patients & 17 & 9/59 patients & 58 (1 year) \\
\hline $\begin{array}{l}\text { Langhlin et al. } \\
\text { 1996-2001 (30) }\end{array}$ & 150 & $16-60$ & $2 / 6$ & $27(25-29)$ & $60(54-71)$ & $\begin{array}{l}\text { In } 150 \text { patients } \\
\text { Grades II, III, IV : } \\
41\end{array}$ & & $35 / 69$ & 19 (2-3 years) \\
\hline $\begin{array}{l}\text { Barker et al. 2000- } \\
2003 \\
\text { (4) }\end{array}$ & 23 & $24(13-53)$ & $\begin{array}{l}\text { Double UCB } \\
\text { trial : } \\
4-6 / 6 \text { matched } \\
\text { each cord and } \\
\text { the recipient }\end{array}$ & $23(15-41)$ & na & 52 & 13 & $5 / 23$ patients & 57 (1 year) \\
\hline $\begin{array}{l}\text { Ballen et al } \\
2003-2005 \text { (15) }\end{array}$ & 19 & $49(24-63)$ & $\begin{array}{l}\text { Double UCB } \\
\text { trial : } \\
4-6 / 6 \text { matched } \\
\text { to each other } \\
\text { and to the } \\
\text { recipient }\end{array}$ & $20(15-34)$ & $41(21-55)$ & 53 & 5 & $5 / 16$ patients & 71 (1 year) \\
\hline $\begin{array}{l}\text { Brunstein et al. } \\
2001-2005 \text { (16) }\end{array}$ & 106 & $51(17-69)$ & $\begin{array}{l}\text { Double UCB } \\
\text { trial : } \\
4-6 / 6 \text { matched } \\
\text { to each other } \\
\text { and to the } \\
\text { recipient }\end{array}$ & $12(0-32)$ & $49(0-134)$ & $\begin{array}{l}37 / 110 \text { patients ( } 4 \\
\text { without hemato } \\
\text { malignancies) }\end{array}$ & $22 / 110$ & $23 / 110$ & 45 (3 years) \\
\hline $\begin{array}{l}\text { Takahashi et al. } \\
2007 \text { (12) }\end{array}$ & 100 & 38 median & & $85 \%$ & na & $\mathrm{Na}$ & $\begin{array}{l}52 \text { (Grade II- } \\
\text { IV) }\end{array}$ & $71 \%$ & 70 (3 years) \\
\hline $\begin{array}{l}\text { Kumar et al. } \\
2008 \text { (31) }\end{array}$ & 173 & 38 median & & $\mathrm{Na}$ & na & $\mathrm{Na}$ & $\begin{array}{l}32 \text { (Grade II- } \\
\text { IV) }\end{array}$ & $28 \%$ & 36 (2 years) \\
\hline $\begin{array}{l}\text { Astuta et al. } 2009 \\
\text { (13) }\end{array}$ & 114 & 34 median & & $\mathrm{Na}$ & na & $\mathrm{Na}$ & $\begin{array}{l}28 \text { (Grade II- } \\
\text { IV) }\end{array}$ & $27 \%$ & 45 (2 years) \\
\hline $\begin{array}{l}\text { Brunstein et al. } \\
2010 \text { (17) }\end{array}$ & 351 & 37 median & & $0,5(0,42-0,6)$ & na & & $\begin{array}{l}0,55(0,42- \\
0,72)(\text { Grade } \\
\text { II-IV) }\end{array}$ & $\begin{array}{l}1,36 \%(0,99- \\
1,88)\end{array}$ & $\begin{array}{l}0,97(0,92- \\
1,35)\end{array}$ \\
\hline
\end{tabular}




\section{Non oncology}

Most indicated use of UCB units in non haematopoietic diseases remains the primary immune deficiencies. HSCT from an HLA-matched donor was in fact shown to correct the immune system in children ${ }^{[33]}$. As indicated in Table 3,

successful and overall survival after UCBT was found to be dependent on the degree of HLA disparity ${ }^{[34]}$. Other studies suggested that higher infused cell doses can partially reduce the impact of HLA disparity on survival ${ }^{[8]}$.

Table 3 : Umbilical Cord Blood Transplantation in Patients with non haematopoietic malignancies

\begin{tabular}{|c|c|c|c|c|c|c|}
\hline Reference & Disease & Number & $\begin{array}{l}\text { Age or } \\
\text { median }\end{array}$ & $\begin{array}{c}\text { Neutrophil engraftment } \\
\text { median or \% }\end{array}$ & Chronic GVHD & $\begin{array}{c}\text { Overall } \\
\text { survival \% }\end{array}$ \\
\hline $\begin{array}{l}\text { Prasad et al. } \\
2008(32)\end{array}$ & $\begin{array}{l}\text { Inherited metabolic disorders } \\
\text { - Hurler Syndrome } \\
\text { - Metachromatic } \\
\text { Leukodystrophy } \\
\text { - Krabbe Diseases } \\
\text { - Sanfilipo Syndrome } \\
\text { - Adrenoleukodystrophy }\end{array}$ & $\begin{array}{l}159 \\
45 \\
15 \\
36 \\
19 \\
13\end{array}$ & na & $\mathrm{Na}$ & na & $\begin{array}{l}77 \text { (1 year) } \\
65 \text { ( } 1 \text { year }) \\
74 \text { (1 year) } \\
79 \text { (1 year) } \\
77 \text { ( } 1 \text { year) }\end{array}$ \\
\hline $\begin{array}{l}\text { Frangaul H. et al } \\
1999-2003 \text { (33) }\end{array}$ & Primary immune Deficiencies & 364 & $0,2-7,8$ & $58 \%$ (day 42 ) & na & 63 (1 year) \\
\hline $\begin{array}{l}\text { Bizzetto et al } \\
\text { 2011(34) }\end{array}$ & Hereditary BM failure & 64 & na & $\begin{array}{l}95 \% \text { of R CBT } \\
86 \% \text { of UR CBT }\end{array}$ & $\begin{array}{l}\text { Acute GVHD II-IV : 2/20 } \\
\text { Chronic } 11 \% \text { (2 years) } \\
\text { Acute GVHD II-IV : } 24 \% \\
\text { (day 100) } \\
\text { Chronic GVHD 53\% } \\
\text { (2 years) }\end{array}$ & $\begin{array}{l}95 \text { (3 years) } \\
61 \text { (3 years) }\end{array}$ \\
\hline
\end{tabular}

NA : not available

R CBT : Related Cord Blood Transplantation

UR : Unrelated Cord Blood Transplantation 


\section{STATE OF THE ART OF UCB BANKING: Public or Private?}

Public banks are for non-profit and are financed by public funds. They are involved in collecting from anonymous consent donors after baby's delivery, processing and conserving UCB units in a registry for allogenic use. For inclusion in the registry, samples are screened based on volume, cell number, tissue types, health history and infectious diseases status. The units are then made available to suitably matched recipients. A great societal benefit is obtained from this UCB altruistic donation, especially for populations with ethnic minorities. Registries of these units in public banks have become a mandatory instrumental tool for haematopoietic transplantation or applications in regenerative medicine. Reports from the Bone Marrow Donors worldwide until April 2013 indicate that there were 571,318 unrelated UCB units banked from 31 countries. To date, more than 10,000 patients have received an UCB transplant worldwide.

IParallel to these public banks, an entire industry has developed. These private (for-profit) banks improve, for a fee, collection of blood samples and cryo-preservation of UCB units for a future use for the child or a related family member for related or allogeneic transplantation. While public banks use well established criteria for UCB units storage, private banks generally store all collected units, leading to a less quality parameter than in public banks ${ }^{[35]}$.

To meet the increasing demand in therapeutic use of UCB, the number of Public UCB banks is growing. There are now nearly 142 public banks as against 134 private banks, which are actively involved around the world with more than 780,000 units ${ }^{[36]}$.

The total number of UCB units in private banks exceeds largely the number conserved in the public ones. Conversely, the units from the former are the mostly used for transplantation. In addition, the probability for a child to be transplanted with his own cells ranges from $1: 2,500$ to $1: 200,000$ if these are not available for his family members [37]. Indeed, more than 180 autologous UCBT has been successfully reported by private banks for non-malignant diseases (Cord Blood Registry in USA), the use of UCB units in malignant conditions being unlikely limited by the presence of pre-leukemic cells ${ }^{[38]}$. Also, the success rates of sibling UCB transplants from a family member are well defined than of transplants from a public donor's UCB and this is more important for ethnic populations ${ }^{[39]}$.

Many ethical debates have sparked regarding conflicting interests between private banks and the public ones and this public-private divide appears to have arisen because of the economic challenges of the UCB banks. Private banks encourage parents to store their child's UCB as a form of biological insurance for the child itself or a family members. In these companies, communication and marketing efforts are made to open up this use to a large part of population. Autologous UCB cells couldn't be used to treat genetic diseases because they carry the same genetic disease, and when required $\mathrm{HSC}$ are largely harvested from $\mathrm{BM}$ or $\mathrm{PB}{ }^{[42,36]}$.
Meanwhile, the current development of public sector policies regarding stem cells manipulation and with the increasing evidence for more therapeutic use of UCB stem cells outside of transplantation (as in regenerative medicine or in immune modulation) make them attractive to the private banks ${ }^{[43,44]}$ and approaches to accommodate between public banks and personal interest in cord blood are unlikely to be achieved.

Even if private banks have developed extensive procedures for collection and storage, and benefit rapidly from advanced biotechnology, their emergence had created disagreements about the future lack of UCB units in public banks to provide treatments of some malignant diseases such as leukemia and lymphoma, and especially in health care systems democratization and ownership of human tissues. Moral questions about how to design a health care system ensuring wellbeing, commitment of generational and social fairness, social solidarity with developing these emerging tissue economies should have answers ${ }^{[45]}$.

Hybrid banks are gaining popularity in some countries, and companies are collecting UCB units for personal use of families and at the same time other units for unrelated use (national). Many private banks now offer UCB to matched family members of a child and include them in research projects. So, the line between private and public banks is likely to be blurred. Seems to be a functional model ensuring therapeutic and economic challenges ${ }^{[43]}$.

\section{LEGISLATION AND BIOETHICS}

Most experts agree that public UCB banking is the only option to obtain a suitable transplant to a vast number of people specifically for heterogeneous populations. These public banks are typically funded in part or entirely by public funds and their primary goal is the creation of an inventory of UCB units for unrelated use. They are envisaged either for solidarity and fair access to healthcare treatment purposes.

The USA and the European Union have not only regulated the therapeutic use of UCB for cell therapies and regenerative medicine, but also the banking of UCB units and the manufacture of manipulated stem cells. At the European level, cell therapy products are considered as medicinal products or as industrially produced medicinal products according to drug registration of innovative therapies system (MTI). They can also be considered as cell therapy preparations implemented in cell therapy units without the status of pharmaceutical establishment. Most of these countries have published statements on UCB and specific documents from the competent health authority, such as "l'Agence de biomédecine in France" or the FDA (Food and Drug Administration). Standards and specific international accreditations are drawn for all the process (from the collection to the distribution for transplantation). Since 2004, the main firms of biotechnology launched in applications on muscular dystrophy, bone damage, cartilage, type I diabetes, mesenchymal stem cells, diseases of the central nervous system and regulatory $\mathrm{T}$ cells.

There is a general consensus and a collaborative effort to establish international guidelines for better use of UCB and 
cell products for cell therapies. The NetCord-Fact international standard $[46,47]$ is now the reference for inspection and accreditation programs for standards cord blood collection, banking and release for administration.

The European Group on Ethics in Science and New Technologies has taken a position on the ethical aspects of the private cord blood banking. Even autologous or family sibling banking is unlawful in some countries, some of them (Italy and Spain) regulate transport and storage in foreign accredited private banks in Switzerland and England where public banks coexist with the private ones.

In contrast to Europe where there is a strong bias in favor of public banks ${ }^{[41,42]}$, United States is less critical of private banking despite of the negative position of some professional organizations such as the American Academy of Pediatrics (AAP) ${ }^{[48]}$. In Australia, UCB transplantation is restricted to recognized applications and specific ethical issues are associated with the collection, storage and access ${ }^{[49]}$. The Canadian Blood Services provide UCB units for banking and research in parallel to existing private banks ${ }^{[50]}$

In some countries of Asia, UCB stem cell banking is permissible and all UCB banks are regulated strictly as the blood banks such as in India. In China, there is only one public bank whereas in Japan and Korea private banks are a majority ${ }^{[51]}$. In the absence of a clear regulation to govern the status of stem cell banks, some Eastern Arab countries banks are created as agents to well-known banks outside (as Future Health, Cells4Life, Cytocare,...). In Iran, public bank provides UCB banking since 2012 with more than 3000 units. In some other countries such as Oman and Lebanon, public and private banks co-exist and provide tissue banking [52]. Saudi Arabia, United Arab Emirates (UAE), and Qatar have recently launched important programs for promoting medical innovations and create public funding to support bank creation and processing ${ }^{[53]}$. Jordan, Saudi Arabia and Qatar have currently private banks and undergo general regulations for the first and religious decrees for the latter while Banks in UAE are under specific laws ${ }^{[53]}$.

In North Africa, ministry of public health of Algeria gave permission to UCB bank in 2010 where collection and processing of UCB units were performed since $2000{ }^{[54]}$. Ethical committee remains the official authority regulating all the process since collection to transplantation. Egypt has two private banks licensed to keep cord blood cells, and three other banks are waiting for license, but the practice of stem cell therapy is limited by the Ministry of health and population to only two public centers of excellence ${ }^{[55]}$. The Tunisian UCB bank follows the guidelines by well-established national laws dealing deontological practices and ethics and is established in the Centre National de Transfusion Sanguine [56]

\section{MOROCCO: The first CB bank}

In Morocco, the first hematology department was created in Casablanca in 1980 and it is still the only public facility where adult patients can be treated for hematological diseases. Pediatric hematological disorders and cancer are treated in two other units. Some patients are treated in private clinics located in Casablanca and Rabat. The public hospitals still have limited resources and rely heavily on non-governmental organizations to take care of these patients ${ }^{[57]}$. The number of equipped bed ward remains insufficient while therapeutic needs of stem cell transplantations are well identified in children and adult patients and matched related family donors are not usually found. Unfortunately, only two allogeneic bone marrow transplantations have been realized till now. In addition, the cost of the transplantation procedure, in case of presence of matched donors, couldn't be supported by all population in the society.

But, the biggest obstacle to implementation of a UCB bank remains the revision of the law of organ donation and clinical trial authorization. While the world highlights the scientific and therapeutic advancement of embryonic and adult stem cells, efforts of Moroccan health system promote most often allopathic treatments. This, is due, in general, to the noncommitment of Moroccan laws to the international advancements in stem cell therapy and to many other medical devises. While infrastructures are evolving with regard to national and international standards quality, and high technological equipments are available, laws regulating clinical applications in new fields are still lagging behind.

\section{Legislation}

The law No. 16-98 relating to organ donation does not allow the altruistic donation, even free. However, the collection of organs from brain dead person is finally allowed for the future organ bank. It remains that the anonymous collection of UCB, considered as "surgical waste" and it is ex-vivo manipulation and unrelated administration are simply prohibited, even if the therapeutic need is justified (in sibling family in the case of hematological malignancies).

\section{Ethic between the social benefit and the financial profit}

The issues related to the creation of a stem cell bank, revealed by the feasibility study carried out by our laboratory since 2008 using a questionnaire distributed in the maternity of the Centre Hospitalier Universitaire (CHU) lbn Rochd in Casablanca (In press) are multiples and are important.

Clinicians interested in these new therapies could more easily find stem cells or other cell products for some transplants in the absence of organ donors and an established organ bank (example type I diabetes). Areas of medical applications are multiples and concern oncology, endocrinology, kidney disease, severe burns, immunotherapy, toxicological studies, muscular dystrophy and neurodegenerative diseases. These applications can generate significant financial returns provided that adequate legislation is in place and a good financial model is identified.

The existing national ethic committees created by ministerial decree have just an advisory role and couldn't have an executive action, especially with no specific drawn rules. However, its main and first goal is to make cell therapies accessible for all the population.

\section{RECOMMENDATIONS}

Morocco should follow some guidelines and recommendations for its attractiveness and competitiveness in the field of UCB cell therapy. These recommendations focus on the legal and technical aspects of the use of stem 
cells or their derivatives in therapy and should be proposed in official texts.

To facilitate integration of cell therapy, several critical points should be considered:

- Allow altruistic donations of UCB cells and regulating their prelevment and transport to the processing laboratory;

- Allow expansion of ex-vivo stem cells and the production of manipulated stem cells for cell therapy;

- $\quad$ Create the institution involved in the manipulation and conservation of the stem cells derived UCB units and derivatives, and authorize their marketing through the creation of a national UCB bank;

- Promote a public bank but allow private transplant centers in the same way as the public one's to practice stem cell therapies;

- Allow biomedical research with cell therapy products derived from UCB and cord matrix by conducting trials for clinical validation of new treatment protocols and authorize the use of these products in public and private institutions approved in advance by the Ministry of Health;

- $\quad$ Authorize the export of these UCB units to international transplant centers to be used as unrelated donor transplant to our residents abroad (MRE);

- Adopt a policy of pricing and reimbursement of these UCB units and derivatives to encourage public institutions to carry out treatments and projects in clinical phase.

There is also need for the creation of a group of experts which can play a role of a regulatory agency rule on requests, for authorizations of advanced UCB stem cell therapy for biomedical research implementation. This group may also give opinion on the changes in biomedical research using stem cell products, or in case of serious side-effects observed after administration of the therapeutic. Steering committees can also be created with various objectives and timelines. This committee will define and approve new clinical investigations related to national priorities in terms of public health, cost and ethics.

\section{CONCLUSION}

Our prime goal is to consider the therapeutic benefit of the stem cell products and derivatives and to make stem cell therapy accessible to Moroccan people. On the other hand, many misconceptions about donation of organs or blood are floated by illiterate and ignorant people and creating doubts about what is going to be done with them. In Arabic and Muslim cultures, people are educated to make offerings of their property, money and time, but never from themselves, even if the religion does not prohibit this type of donation. So, considerable efforts have to be made to educate large numbers of people and especially parents regarding UCB use and laws by creating public awareness and strenghthening the network between authorities, professional associations, physicians, non-governmental organizations and opinion leaders.

\section{REFERENCES}

1. Gluckman E, Broxmeyer H A, Auerbach A D, Friedman HS, Douglas GW, Devergie A, Esperou H, Thierry D, Socie G, Lehn P, et al. Hematopoietic reconstitution in a patient with Fanconi's anemia by means of umbilical cord blood from an HLA-identical sibling. N. Eng. Med. 1989; 321(17):1174-1178.

2. Rocha V, Cornish J, Sievers EL, Filipovitch A, Locatelli F, Peters C, Remberger M, Michel G, Arcese W, Dallorso S, Tiedemann K, Busca A, Chan KW, Kato S, Ortega J, Vowels M, Zander A, Souillet G, Oakill A, Woolfrey A, Pay AL, Green A, Garnier F, lonescu I, Wernet P, Sirchia G, Rubinstein $P$, Chevret $S$, Gluckman E. Comparison of outcomes of unrelated bone marrow and umbilical cord blood transplants in children with acute leukemia. Blood 2001;97(10):2962-2971.

3. Dalle JH, Duval M, Moghrabi A, Wagner E, Vachon MF, Barette S, Bernstein M, Champagne J, David M, Demers J, Rousseau P, Winikoff R, Champagne MA. Results of an unrelated transplant search strategy using partially HLAmismatched cord blood as an immediate alternative to HLA-matched bone marrow. Bone Marrow Transplant 2004; 33(6): 605-611.

4. Barker JN, Weisdorf DJ, Defor TE, Blazar BR, McGlave $\mathrm{BP}$, Miller JS, Verfaillie CM, Wagner JE. Transplantation of 2 partially HLA-matched umbilical cord blood units to enhance engraftment in adults with hematologic malignancy. Blood 2005;105(3): 1343-1347.

5. Eapen M, Rocha V, Sanz G, Scaradavou A, Zhang MJ, Arcese W, Sirvent A, Champlin RE, Chao N, Gee AP, Isola L, Langhlin MJ, Marks DI, Nabhan S, Ruggeri A, Soiffer R, Horowitz MM, Gluckman E, Wagner JE. Effect of graft source on unrelated donor haematopoietic stem-cell transplantation in adults with acute leukemia: a rretrospective analysis. Lancet Oncol. 2010(7);11:653-660.

6. Kogler G, Calleias J, Hakenbern P, Enczmann J, Adams O, Daubener W, Krempl C, Gobel U, Somville T, Wernat $P$. Hematopoietic transplant potential of unrelated cord blood : Critical issues. J Hematother 1996;5(2):105-116.

7. Eapen M, Rubinstein P, Zhang MJ, Stevens C, Kurtzberg J, Scaradavou A, Lobenza FR, Champlin RE, Klein JP, Horowitz MM, Wagner JE. Outcomes of transplantation of unrelated donor umbilical cord blood and bone marrow in children with acute leukemia: a comparison study. Lancet 2007;369(9577):1947-1954.

8. Wagner JE, Barker JN, DeFor TE, Baker KS, Blazar BR, Eide C, Goldman A, Kersey J, Krivit W, MacMillan ML, Orchard PJ, Peters C, Weisdorf DJ, Ramsay NK, Davies SM. Transplantation of unrelated donor umbilical cord blood in 102 patients with malignant and nonmalignant diseases: influence of CD34 cell dose and HLA disparity on treatment-related mortality and survival. Blood. 2002;100(5):1611-8.

9. Atsuta $\mathrm{Y}$, Kanda J, Takanashi M, Morishima $\mathrm{Y}$, Taniguchi $\mathrm{S}$, Takahashi S, Ogawa H, Ohashi K, Ohno Y, Onishi $\mathrm{Y}$, Aotsuka N, Nagamura-Inoue T, Kato K, Kanda Y; HLA Working Group of the Japan Society for Hematopoietic Cell Transplantation. Different effects of HLA disparity on transplant outcomes after single-unit cord blood transplantation between pediatric and adult patients with leukemia. Haematologica. 2013;98(5):814-22.

10. Migliaccio AR, Adamson JW, Stevens CE, Dobrila NL, Carrier CM, Rubinstein P. Cell dose and speed of engraftment in placental/umbilical cord blood transplantation: graft progenitor cell content is a better predictor than nucleated cell quantity. Blood. 2000;96(8):2717-22. 
11. Kang HJ, Yoo KH, Lee JW, Kim H, Lee SH, Sung KW, Park KD, Koo HH, Shin HY, Ahn HS. Double umbilical cord blood transplantation for children and adolescents. Ann Hematol. 2010;89(10):1035-44.

12. Takahashi S, Ooi J, Tomonari A, Konuma T, Tsukada N, Oiwa-Monna M, Fukuno Kmchiyana M, Takasugi K, Iseki T, Tojo A, Yamaguchi T, Asano S. Comparative signleinstitute analysis of cord blood transplantation from unrelated donors with bone marrow or peripheral blood stem-cell transplants from related donors in adult patients with hematologic malignancies after myeloablative conditioning regimen. Blood 2007; 109(3): 1322-1330.

13. Atsuta $Y$, Suzuki $R$, Nagamura-Inoue $T$, Taniguchi $S$, Takahashi S, Kai S, Sakamaki H, Kouzai Y, Kasai M, Fukuda T, Azuma H, Takamashi M, Okamoto S, Tsuchido M, Kowa K, Morishima Y, Kodera Y, Kato S. Diseasespecific analyses of unrelated cord blood transplantation compared with unrelated bone marrow transplantation in adult patients with acute leukemia. Blood 2009;113(8):1363-1638.

14. Fernandes JF, Rocha V, Labopin M, Neven B, Moshous D, Gennery AR, Friedrich W, Porta F, Diaz de Heredia C, Wall D, Bertrand $Y$, Veys $P$, Slatter $M$, Schulz A, Chan KW, Grimley M, Gungor T, Ayas M, Ebell W, Kalwak K, Taupin P, Blanche S, Gaspar HB, Landais P, Fischer A, Gluckman E, Cavazzana-Calvo M. Enrocord and Inborn Errors working party of european group for blood ans marrow transplantation. Transplantation in patients with SCID: mismatched related stem cells or unrelated cord blood? Blood. 2012;119 (12):2949-55.

15. Ballen KK, Spitzer TR, Yeap BY, McAfee S, Dey BR, Attar E, Haspel R, Kao G, Liney D, Alyea E, Lee S, Cutler C, Ho $\mathrm{V}$, Soiffer R, Antin JH. Double unrelated reduced-intensity umbilical cord blood transplantation in adults. Biol Blood Marrow Transplant. 2007;13(1):82-9.

16. Brunstein CG, Barker JN, Weisdorf DJ, DeFor TE, Miller JS, Blazar BR, McGlave PB, Wagner JE. Umbilical cord blood transplantation after non-myeloablative conditioning: impact on transplantation outcomes in 110 adults with hematologic disease. Blood 2007;110(8):3064-3070.

17. Brunstein CG, Gutman JA, Weisdorf DJ, Woolfrey AE, Defor TE, Gooley TA, Verneris MR, Appelbaum FR, Wagner JE, Delaney C. Allogeneic hematopoietic cell transplantation for hematologic malignancy: relative risks and benefits of double umbilical cord blood. Blood. 2010;116(22):4693-9.

18. Gluckman E, Rocha V. Donor selection for unrelated cord blood transplants. Current Opin Immunol 2006;18(5):565570.

19. Rocha V, Wagner JE Jr., Sobocinski KA, Klein JP, Zhang MJ, Horowitz MM, Gluckman E. Graft-versus-host-disease in children who have received a cord-blood or bone marrow transplant from an HLA-identical sibling. Eurocord and International Bone Marrow Registry Working Committee on Alternative Donor and Stem cell Sources. N. Engl. J. Med. 2000;342(25):1846-1854.

20. Szabolcs P, Niedzwiecki D. Immune reconstitution after unrelated cord blood transplantation. Cytotherapy. 2007;9(2):111-22.

21. Yi ES, Lee SH, Son MH, Kim JY, Cho EJ, Lim SJ, Cheuh $\mathrm{HW}$, Yoo KH, Sung KW, Koo HH. Hematopoietic stem cell transplantation in children with acute leukemia: similar outcomes in recipients of umbilical cord blood versus marrow or peripheral blood stem cells from related or unrelated donors. Korean J. Pediatr. 2012; 55(3): 93-99.

22. Barker JN, Davies SM, Defor T, Rampsey NK, Weisdorf DJ, Wagner JE. Survival after transplantation of unrelated donor umbilical cord blood is comparable to that of human leukocyte antigen-matched unrelated donor bone marrow: results of a matched-pair analysis. Blood 2001;97(10):2957-2961.

23. Wagner JE, Rosenthal J, Sweetman R, Shu XO, Davies SM, Ramsay NK, McGlave BP, Sender L, Cairo MS. Successful transplantation of HLA-matched and HLA- mismatched umbilical cord blood from unrelated donors : analysis of engraftment and acute graft-versus-host disease. Blood 1996;88(3):795-802.

24. Gluckman E, Rocha V, Boyer-Chammard A, Locatelli $F$, Arcese W, Pasquini R, Ortega J, Souillet G, Ferreira E, Laporte JP, Fernandez M, Chastang C. Outcome of cordblood transplantation from related and unrelated donors. Eurocord Transplant Group and the European Blood and Marrow Transplantation Group. N. Engl. J. Med. 1997;337(6):373-381.

25. Kutzberg J, Prasad VK, Carter SL, Wagner JE, BaxterLowe LA, Wall D, Kapoor N, Guinan EC, Feig SA, Wagner EJ, Kernan NA, COBLT Steering Committee. Results of the Cord Blood Transplantation Study (COBLT): clinical outcomes of unrelated donor umbilical cord blood transplantation in pediatric patients with hematologic malignancies. Blood 2008;112(10):4318-4327.

26. Smith AR, Baker KS, Defor TE, Verneris MR, Wagner JE, Macmillan ML. Hematopoietic cell transplantation for children with acute lymhpoblastic leukemia in second complete remission: similar outcomes in recipients of unrelated marrow and umbilical cord blood versus marrow from HLA-matched sibling donors. Biol. Blood Marrow Transplant 2009;15(9):1086-1093.

27. Yoo KH, Lee SH, Sung KW, Koo HH, Chung NG, Cho B, Kim HK, Kang HJ, Shin HY, Ahn HS, Baek HJ, Han DK, Kook H, Hwang TJ, Kin SY, Lee YH, Hah JO, Im HJ, Seo JJ, jung HJ, Park SS, Lim YT, Yoo ES, Ryr KH, Park HJ, Park BK. Current status of pediatric umbilical cord blood transplantation in Korea: a multicenter retrospective analysis of 236 cases. AM; J. Hematol 2011:86(1);12-7.

28. Kato K, Yoshimi A, Ito E, Oki K, Hara J, Nagatoshi Y, Kikuchi A, Kobayashi R, Nagamura-Inove T, Kai S, Azuma $\mathrm{H}$, Takanochi M, Isoyama $\mathrm{K}$, Kato $\mathrm{S}$. Cord blood transplantation from unrelated donors for children with acute lymphoblastic leukemia in Japan : the impact of methotrexate on clinical outcomes. Biol Blood Marrow Transplant 2011;17(12):1814-1821.

29. Rocha V, Labopin M, Sang G, Arcese W, Schwerdtfeger R, Bosi A, Jacobsen N, Ruutu T, de Lima M, Finke J, Frassoni F, Gluchman E. Transplants of umbilical-cord blood or bone marrow from unrelated donors in adults with acute leukemia. N. Engl. J. Med. 2004;351(22):2276-2285.

30. Laughlin MJ, Eapen M, Rubinstein P, Wagner JE, Zhang MJ, Champlin RE, Stevens C, Barker JN, Gale RP, Lazarus HM, Marks DI, van Rood JJ, Scaradavou A, Horowitz MM. Outcomes after transplantation of cord blood or bone marrow from unrelated donors in adults with leukemia. N. Engl. J. Med. 2004;351(22):2265-2275.

31. Kumar P, Defor TE, Brunstein C, Barker JN, Wagner JE, Weisdorf DJ, Burns LJ. Allogeneic hematopoietic stem cell transplantation in adult acute lymphocytic leukemia: impact of donor source on survival. Biol Blood Marrow Transplant 2008;14(12):1394-1400.

32. Prasad VK, Mendizabal A, Parikh SH, Szabolcs P, Driscoll TA, Page K, Lakshminarayanan S, Allison J, Wood S, Semmel D, Escolar ML, Martin PL, Carter S, Kutzberg J, . Unrelated donor umbilical cord blood transplantation for inherited metabolic disorders in 159 pediatric patients from a single center : influence of cellular composition of the graft on transplantation outcomes. Blood 2008;112(7):2979-2989.

33. Frangoul H, Wang L, Harrell Jr FE, Manes B, Calder C, Domm J. Umbilical cord blood transplantation in children with immune deficiency: results of a multicenter study. Bone Marrow Transplant 2010;45(2):283-288.

34. Bizzetto R, Bonfim C, Rocha V, Socié G, Locatelli F, Chan K, Ramire O, Stein G, Nabhan S, Miranda E, Passweg J, De Souza CA, Gluckman E, Eurocord and SAA-WP. Outcomes after related and unrelated umbilical cord blood transplantation for heredity bone marrow failure syndromes other than Fanconi anemia. Haematologica 201;96(1):134-141. 
35. Sun J, Allison J, McLaughlin C, Sledge L, Waters-Pick B, Wease S, Kurtzberg J. Differences in quality between privately and publicly banked umbilical cord blood units: a pilot study of autologous cord blood infusion in children with acquired neurologic disorders. Transfusion. 2010;50(9):1980-7.

36. Ballen KK, Barker JN, Stewart SK, Greene MF, Lane TA. American Society of Blood and Marrow Transplantation. Collection and preservation of cord blood for personal use. Biol Blood Marrow Transplant. 2008;14(3):356-63.

37. Sullivan MJ. Banking on cord blood stem cells. Nat Rev Cancer. 2008;8(7):555-63

38. Greaves M. Pre-natal origins of childhood leukemia. Rev Clin Exp Hematol. 2003;7(3):233-45.

39. Gluckman E, Ruggeri A, Rocha V, Baudoux E, Boo M, Kurtzberg J, Welte K, Navarrete C, van Walraven SM; Eurocord, Netcord, World Marrow Donor Association and National Marrow Donor Program. Family-directed umbilical cord blood banking. Haematologica. 2011;96(11):1700-7.

40. Comité Consultatif National d'Ethique pour les Sciences de la Vie et de la Santé (CCNE) : Avis 74- Les banques de sang de cordon ombilical en vue d'une utilisation autologue ou en recherche. 12 Décembre 2002. Available at : www.ccne-ethique.fr/docs/fr/avis074.pdf.

41. Katz G, Mills A, Garcia J, Hooper K, McGuckin C, Platz A, Rebulla P, Salvaterra E, Schmidt AH, Torrabadella M. Banking cord blood stem cells: attitude and knowledge of pregnant women in five European countries. Transfusion. 2011;51(3):578-86.

42. Edozien LC. NHS maternity units should not encourage commercial banking of umbilical cord blood. BMJ. 2006;333(7572):801-4.

43. O'Connor MA1, Samuel G, Jordens CF, Kerridge IH. Umbilical cord blood banking: beyond the public-private divide. J Law Med. $2012 ; 19(3): 512-6$.

44. Walbdy C. Umbilical cord blood from social gift to venture capital. BioSciences 2006; 1: 55-70.

45. Stewart CL., Aparicio LC, Kerridge IH. Ethics and law 2013; MJA 199(4): 290-292.

46. Standards for cellular therapy product services. 2nd ed. Bethesda MD: American Association of Blood Banks; 2007.

47. International standards for cord blood collection, processing, testing, banking, selection and release. 3rd ed. Bethesda, MD: American Association of Blood Banks;

\section{Abbreviations:}

$\begin{array}{ll}\text { UCBT: } & \text { Umbilical Cord Blood Transplantation } \\ \text { HLA: } & \text { Human Leukocyte Antigen } \\ \text { BM: } & \text { Bone Marrow } \\ \text { PB: } & \text { Peripheral Blood } \\ \text { GVHD: } & \text { Graft Versus Host Disease } \\ \text { MRD: } & \text { Matched-related Donor } \\ \text { URD: } & \text { Unrelated Donor } \\ \text { HSCT: } & \text { Haematopoietic Stem Cell Transplantation } \\ \text { R CBT: } & \text { Related Cord Blood Transplantation } \\ \text { UR CBT: } & \text { Unrelated Cord Blood Transplantation }\end{array}$

2006. Net Cord Foundation for the Accreditation of Cellular Therapy

48. Parents' guide to Cord Blood Foundation. Cord blood regulations, by state. United States of America. 2012. (cited 2012 Jul 11). Available from: URL: $\mathrm{http} / /$ parentsguidecordblood.org/regulations.

49. Petrini C. Umbilical cord blood collection, storage and use : ethical issues. Blood Transfu 2010;8(3):139-148.

50. Isasi R, Dalpe G, Knoppers BM. Fostering public cord blood banking and research in Canada. Stem Cells Dev. 2013;22 Suppl 1:29-34.

51. Petrini C. Ethical issues in umbilical cord blood banking : a comparative analysis of documents from national and international institutions. Transfusion 2013; 53(4): 902909.

52. Jamali $M$, Atarodi $K$, Nakhlestani $M$, Abolghasemi $H$, Sadegh H, Faranoosh M, Golzade K, Fadai R, Niknam F, Zarif MN. Cord blood banking activity in Iran national cord blood bank : A two years experrience. Transfus Apher Sci. 2014;50(1):129-35.

53. Monica M. Matsumoto and Kirstin R.W. Mathews. More than oil and uprisings: Current developments in cord blood banking in the Arab world: Abstract.Science and technology policy program, Baker Institute, Rice University. Houston Texas, Abstract 1316.

54. R. Belhadj, R. Ahmed nacer, M. Benakli, F. Mehdid, N.Rahmoune, M. Baazizi, F. Harieche, F. Zerhouni, M.Derguini, Pr. Bouzekrini, Pr. Adad, RM. Hamladji. Bilan d'activité de la banque de sang de cordon ombilical sur une période de 10 ans (2000-2010). Available at www.hematologie-dz.com/download/cong17_20.pdf.

55. Hany Sleem, MD. Ethical and practice Issues in stem cell Research and Therapy "Egyptian Situation". The 3rd Regional Conference Salim El-Hoss Bioethics and Professionalism Program (SHBPP) American University of Beirut Faculty of Medicine.14 -15 September 2012

56. Mellouli F, Fekih J, Ben Hamed L, Sfar R, Rezigua H, Chilli $\mathrm{H}$, Béjaoui M, Mojaat N, Boukef K.. A cord blood bank in Tunisia: usefulness and feasibility. Tunis Med. 2008 Jan;86(1):15-9.

57. Benchekroun S, Harif M, Madani A, Quessar A, Zafad S, Rachid R. Present and future of hematology and stem cel transplantation in Morocco. Bone Marrow Transplant. 2008;42 Suppl 1:S106-S108. 


\section{Potential Conflicts of Interests:}

None

\section{Acknowledgements:}

We wish to acknowledge all the physicians of the maternity $\mathrm{A}$ and $\mathrm{B}$ of the $\mathrm{CHU}$ Ibn Rochd for their collaboration.

\section{Funding}

This work was partially supported by the Blood Systems Research Institute, 270 Masonic Avenue/ San Francisco, CA 94118, and by EU FP7/2007-2013 grant 260715.

\section{Correspondence to be addressed to:}

Dr. Loubna MAZINI; Laboratoire Cellules Souches et Thérapie Cellulaire,Institut Pasteur Maroc, 1, Place Louis Pasteur, 20 360 Casablanca; Tel: 05224344 60; Fax: 0522260954

Email: loubna.mazini@pasteur.ma 